Kadri Asmer

\title{
LETTERS FROM THE PAST: ARMIN TUULSE'S ARCHIVE IN TARTU
}

The creative legacy of Armin Tuulse (1907-1977, Neumann until 1936), the first Estonian art history professor and scholar of art and architecture, is meaningful in the context of Estonia, as well as Western and Northern Europe. He gained international recognition for his works on medieval architecture, in which he focused on the fortresses, castles and churches of the Baltic and Nordic countries. As a professor at the University of Tartu, and later at Stockholm University, he built a bridge between pre-war art history and its future researchers, and more broadly between Estonia and Sweden. Tuulse's work and teachings became an important guide for his successors, who have continued and supplemented his research work on the Middle Ages. At the University of Tartu, this baton was handed off to Kaur Alttoa, who has been carrying it forward for decades.

In 2015, the correspondence of Armin Tuulse, and his wife Liidia Tuulse (1912-2012) arrived at the Estonian Cultural History Archives from Sweden ${ }^{1}$ and currently needs to be put in order and systematised. Based thereon, it is very difficult to determine the exact size of the archive, but we can speak about hundreds of letters that were sent to Tuulse starting in 1944. A significant part of the archive

DOI: https://doi.org/10.12697/BJAH.2017.13.10

Translated by Juta Ristsoo.

1 Estonian Cultural History Archives of the Estonian Literary Museum, Reg. 2015/53. 


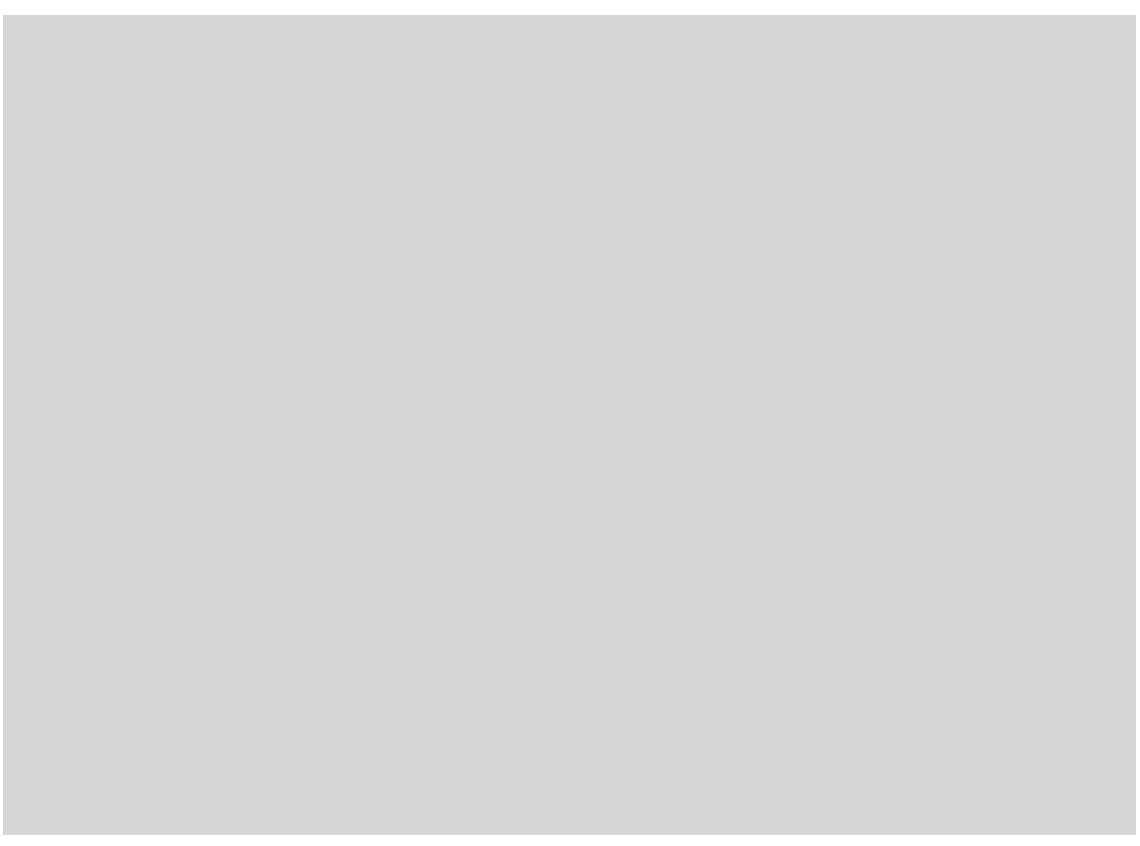

Fig. 1. Armin Tuulse (undated photo). Estonian Cultural History Archives of the Estonian Literary Museum, Tartu.

is comprised of the correspondence between the spouses, along with frequent contacts with exile Estonian cultural figures ${ }^{2}$ and Armin Tuulse's work-related communications with colleagues in Europe, the U.S. and Australia ${ }^{3}$. The main objective of this article is to take a first look at the material and highlight the main points of emphasis in the correspondence of the exile Estonians in the 1940s and 1950s. At that time, the main issue (in addition to worries about everyday hardships and living conditions) was related to the continuation of their work and keeping Estonian culture alive in a foreign cultural and linguistic space.

2 For example: artists Eerik Haamer, Endel Kõks, Eduard Ole, Juhan Nõmmik, Arno Vihalemm, Karin Luts, Jaan Grünberg; art historian Rain (Robert) Rebas; linguists Peeter Arumaa and Julius Jahan Kõpp: medical scientist and university professor Aadu Lü̈̈s; economist, geographer and university professor Edgar Kant; literary scholar Otto Alexander Webermann and many others.

3 For example: from Sweden, art historians Helge Kjellin and Sten Karling, historian, state antiquarian and restorer Sigurd Curman; from Germany historians Paul Johansen and Hellmuth Weiss, art historian Kurt Withelm-Kastner, form Fin land archaeologists and historans Car Jacob Gardberg and Nils Cleve; from the Netherlands, historian Jacob Gerard Nicolaas Renau and many others.

\section{NOTES ON ARMIN TUULSE}

\section{AND THE TEACHING OF ART HISTORY IN TARTU}

In order to understand the importance of Armin Tuulse's work, and more broadly, the developmental direction of art history as an independent discipline at the University of Tartu, one must go back to the last century, to the 1920s and 1930s. As of 1 December 1919, the University of Tartu became an Estonian-language university. Art historian Eero Kangor writes: "The various interests related to the development of Estonian art history as an academic discipline were clearly apparent in the search for and selection of the University of Tartu's Professor of Art History, which took place between 1919 and 1921."4 The model for reorganising the university into Estonia's national university came from the Nordic countries. Initially, the Chair of Art History lacked a professor, and it did not start up until 1922, when Tor Helge Kjellin (1885-1984), who was Swedish and had been selected to fill the position, arrived in Tartu. Nevertheless, as art historian Mart Eller has noted, during the 1920s and 1930s, much of the research related to the study of national art was not coordinated or systematised, but sustained by individual enthusiasts. ${ }^{5}$ A significant step taken during this period was the introduction of the study of Estonia's local cultural space and the distinctive features of the local tradition, and especially architecture, to accompany the teaching of the arts of antiquity, which had dominated until that time. Thus, for instance, Kjellin introduced the innovative approach of treating local medieval sacral architecture in the context of the Northern European art region, instead of narrowly, as German colonial art. ${ }^{6}$

Although many of the other professorships of humanities at the University of Tartu were already being filled by Estonians who had studied at the university, in the uncertain conditions that existed, a strong school comprised of Estonian art historians had yet to develop. This is further confirmed in the year 1933, when one January morning Sten Karling (1906-1987), who was Swede and only 27 years old, came

4 Eero Kangor, "Tartu Ülikooli kunstiajalooõpetuse moderniseerimisest ja kollektsioonide rollist kunstiajaloo professori valimistel aastatel 1919-1921", Tartu Ülikooli ajaloo küsimusi XXXX (2012), 93

5 Mart Eller, "Kunstiajaloo uurimine", Leninlik etapp eesti ajalooteaduses. Histograafilisi artikleid, compiled and ed. by Endel Laul (Tallinn: Eesti Raamat, 1970), 257.

6 Eero Kangor, “Miks ei saanud ühestki tüdrukust kunstiajaloolast?", Sirp, 26.05.2017, 30-31. 


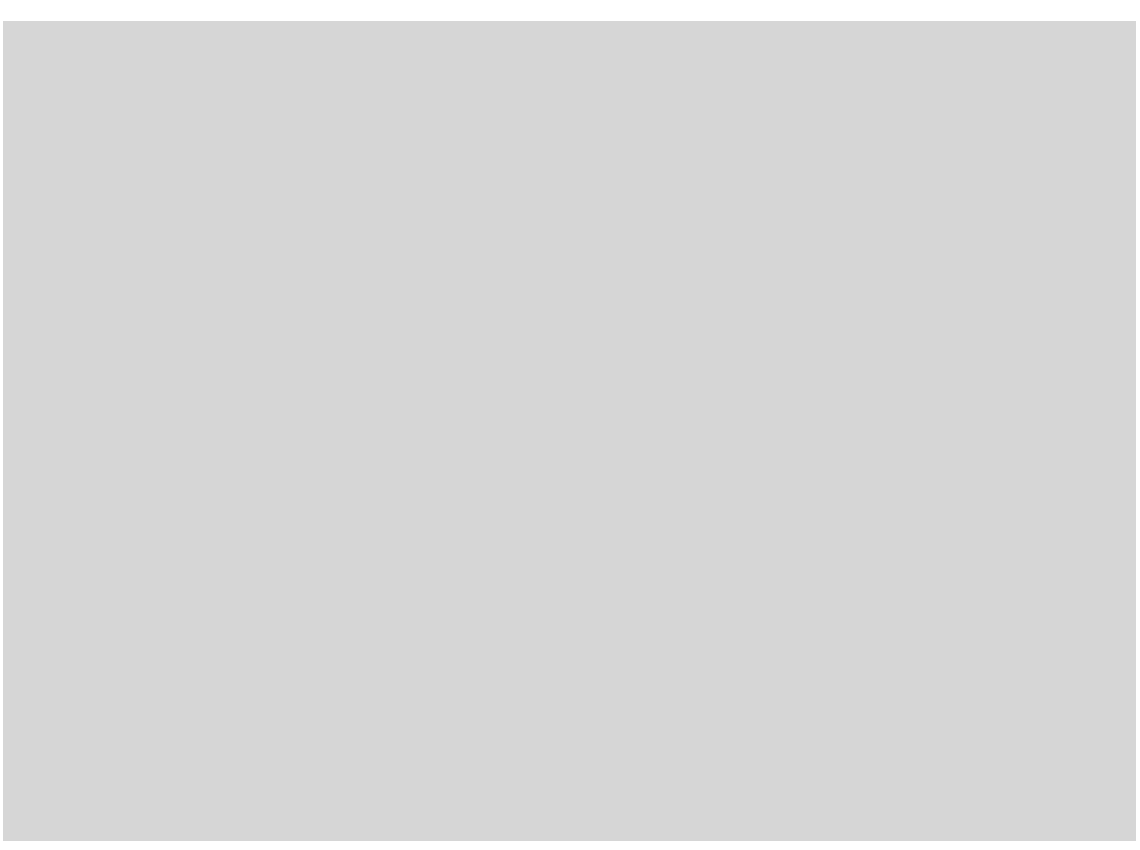

Fig. 2. Sten Karling (undated photo). Estonian Cultural History Archives of the Estonian Literary Museum, Tartu.

to teach art history at the university. His selection and invitation to teach in Tartu was motivated primarily by two circumstances. Firstly, there was a scarcity of local art historians at the national university. Secondly, art history was persistently proceeding along a clear path that would dislodge it from the sphere of influence of the Baltic-German cultural space, and link it more strongly with the Nordic countries. With the arrival of Sten Karling, the study of so-called North-Baltic regional art history was revived after a long interim, and strong contacts were established between Estonia and Sweden. A bright and youthful circle of art historians converged around Karling, which, in addition to Armin Tuulse, included Villem Raam, Helmi Üprus and Ella Vende among others.

Upon Karling's arrival, Armin Tuulse, whose career as a scholar had started in Tartu in 1930, chose art history as his main speciality. What was it about Karling that enabled him to greatly improve the level of art history at the University of Tartu in such a short time, and to have such a great impact on his students? This can be explained by Karling's ability to learn new language very quickly, and by 1938, he was lecturing in Estonian. It is important to note that this attitude was not typical of all the faculty members. For example, Lucien Charles Rudrauf, who had started working as a lecturer in the Chair of Art History in the 1920s, was still giving his lectures in French and German after having spent 10 years at the university Armin Tuulse remembered Karling as a pedagogue filled with ideas, "A great field of work awaited us: Estonian churches with their rich interiors, the medieval castles and old towns were like a great closed book, the pages of which Karling revealed to his enthusiastic listeners on research trips and in the auditorium." ${ }^{7}$

The teacher and the student, whose age difference was only one year, became close friends. This is confirmed by the subsequent correspondence between the two colleagues, the content of which was work-related, concrete and business-like, but in which Karling addressed Tuulse with the words "Broder" ("brother") or "Kär vän" ("dear friend").

Karling also had a direct impact on the specifics of Tuulse's research work, by giving him assignments to research castles, which later turned into MA and PhD theses, and more broadly into his life's work. Thus, Tuulse became primarily a researcher of fortifications, who in additional to architectural analyses and comparisons, turned great attention to the political history and distinctive geographical features of the areas under examination. ${ }^{8}$ Tuulse also dedicated his time and attention to the analysis of general problems related to art life, and to the developments occurring in the fine arts, about which he started to publish critiques while he was still a student. ${ }^{9}$ He also became a passionate promoter and advocate of heritage conservation. This was also apparent in an article he wrote in 1937, which was called "The Castles of the Teutonic Order and Us", in which he calls upon his contemporaries to maintain and preserve for future scientists, that which was considered to be of little value based on the scientific

7 Armin Tuulse, "Sten Karling 50-a.", Teataja, 15.01.1956, 7

8 E.g. Kaur Alttoa, "Armin Tuulse ja Eesti keskaegsed linnused", Kunstiteaduslikke Uurimusi, 3 (17) (2008), 13-22.

9 E.g. Armin Tuulse, "Kunstiprobleeme tänapäeva Saksamaal", Looming, 2 (1938), 195-201; Armin Tuulse, "Mårkmeid Lääne-Euroopa moodsast arhitektuurist", Looming, 10 (1938), 1141 1149; Armin Tuulse, “300 aastat Ameerika kunsti", Kunst ja Kirjandus, 07.08.1938, 117-119; Armin 
principles of the day: "One must wonder at the view that the ruins still have some kind of political importance, and slave blood courses their protectors' veins. Strange that people are so weak that they let themselves be irritated by moss-covered walls! /---/ Seeking reasons for their assertions, they have not forgotten the aesthetic motive the ruins don't fit into the landscape. /---/ Call it romanticism, but people with a sense of beauty still find that the ruins add charm to our landscapes." 10

In the second half of the 1930s, Tuulse continued his studies in Köningsberg, where his mentors were art historians Karl-Heinz Clasen and Wilhelm Worringer. At the same time, ethnologist Gustav Ränk, also studied there. This association turned into a long friendship, which continued during the years of exile in Sweden. In 1977, Ränk recalled their time in Germany together, "During the breaks between studying and researching, we would build air castles in the air as settlements for Estonian science at our homeland university. The mood of war was already in the air; military units, with and without armour, were spread out from one end of the city to the other; at night, planes whirred in the lights cast by the searchlights like bugs in the sky. But, at that time, no one would have guessed that the games these machines were playing would destroy all our dream castles in only a few years."11 In addition to the Köningsberg trip, Tuulse also travelled to the Netherlands, Belgium, France, and Italy. And for a longer period of time in 1938, together with Villem Raam, he attended seminars at Stockholm University organised by Johnny Roosval, an expert on Nordic architecture. In May of the same year, the Postimees newspaper wrote that Raam and Tuulse, who had received scholarships from the Baltic Institute, had arrived back in Tartu, and were very satisfied with the results of their journey. ${ }^{12}$

During the Soviet occupation, Karling was removed from his position at the university in the fall semester of 1940, and the following March, he was forced to leave Estonia. After Karling's departure, Armin Tuulse took over the teaching. The aforementioned trips and information collecting was a prelude to the completion of

10 Armin Tuulse, "Ordulossid ja meie", Akadeemia, 6 (1937), 405-407.

11 Gustav Ränk, "Kohtumisi Armin Tuulsega", Eesti Päevaleht, 23.12.1977, 10.

12 "Balti Instituudi stipendiaadid jõudsid tagasi”, Postimees, 19.05.1938, 7 his PhD thesis titled Die Burgen in Estland und Lettland in 1942, in which he emphasised the impact of the local traditions of Estonia and Latvia on urban architecture. His work focused on establishing a comprehensive connection between the construction of the castles with local nature, the locally available construction materials, and distinctive features of the landscape. Noteworthy is his categorisation of the fortifications on the territory of Estonia and Latvia, which occurred against the background of two great eras - before and after firearms. Apparently Tuulse was aware that the conclusions drawn in the course of this work could not be final, since the material and opportunities for research were limited at that time. The completed paper brought him recognition in wide circles, including outside of Estonia. Regardless of the additions and corrections subsequently made by scholars, his study has not lost its importance, and is still of interest to specialists today.

After defending his PhD thesis, Tuulse became the first Estonian professor of art history. Thus, one can say that the Estonian-language teaching of art history started by Karling was given the stamp of approval in the form of Tuulse. It should also be mentioned that Tuulse was also the first Estonian scholar to have studied at the national university, who focused on the research of local churches and monasteries. Prior to that, it was mostly Baltic Germans who dealt with this, and in a semi-amateurish way. Another exception was Kjellin, but in retrospect, his greatest contribution was to provide the department with specialised literature and teaching materials, and to introduce new ideas. During the years spent in Tartu, Kjellin only produced a modest number of personal research papers.

However, in the context of Estonian cultural history, the contacts that were established and friendships that developed in Tartu were given a new meaning after World War II, when both Kjellin and Karling became key persons in the promotion of exile Estonian cultural life in Sweden and, using their positions in Sweden, opened many helpful doors for the Estonians.

By 1944, Tuulse had a clear idea of Estonia's fate, and he made the difficult decision to leave for Sweden with his family. Armin Tuulse's wife Liidia, who was a poet, has recalled that their departure in August of 1944 was made possible by Sigurd Curman, the Swedish 
state archivist, who organised places for dozens of Estonian scholars ${ }^{13}$ on a ship called 'Juhan', which was to transport Swedes who lived in Estonia back to their homeland. ${ }^{14}$ After Tuulse's departure, art historian Voldemar Vaga was named as the acting head of the department at the university. By the way, when Tuulse left Estonia, he was known not only as an art historian, but also a violinist in the Vanemuine Symphony Orchestra. It is said that, "He was such a good violinist that many people did not believe that he was a university faculty member and scholar..."15 This fact is significant for those who read Tuulse's writings, and may notice, here and there, his habit of comparing art and architecture with the long-form musical works, and using musical terminology in his descriptions.

Tuulse acclimated to life in Sweden thanks to his language skills and familiar colleagues. Thus, Sten Karling praises him in a letter sent on 14 September 1945: "Du kan vara stolt över Din kunskap i svenska!" ("You can be proud of your knowledge of the Swedish language!"). During his first years in exile, Tuulse already attracted attention with his exceptional productivity and diligence. The topics of the first papers that he completed in exile were related to Estonia, but later, through force of circumstance, the subject matter changed to include the cultural space of the Nordic countries and Europe generally. ${ }^{16}$ Tuulse started working as an associate professor at Stockholm University in 1952, and in 1962, he was named Professor of Nordic and Comparative Art History at the same university. He was active at the university until 1974, when due to a serious illness that befell him a year earlier, he could not continue working.

An overview of Tuulse's field of activity would inevitably be long, and the format of this article precludes in-depth treatment of it. But, it should be noted that, in honour of his $60^{\text {th }}$ birthday, a special work was compiled by specialists, and the large number of people

13 In addition to Armin Tuulse, there were others, including historian Evald Blumfeldt, professor of medicine Aadu Lüüs, physicist Villem Koern, etc. Helmut Einpaul, "Rännak ümber Läänemere", Videvik, 25.09.2008, 5 .

14 Liidia Tuulse's presentation "Kohtumised kirjanikega Rootsis" at the National Library in Tallinn on 29 September 2004. Copy of the presentation in Kadri Asmer's possession.

15 “Mees pilliga: mitmekülgne Johannes Taul”, Sirp, 27.09.2002, 21.

16 For instance, in 1952 a comprehensive book called Borgar $i$ Västerlandet, which has been translated into German and English. In 1968, a large-scale research paper in the field of sacral art, or more precisely Romanesque art in Scandinavia: Romansk kont i Norden, which, in additio to Swedish, also appeared in German, Polish and Spanish. who congratulated him included King Gustav VI Adolf of Sweden. ${ }^{17}$ In 1980, he was posthumously awarded the Mare Balticum medal, which recognised his special accomplishments in the preservation of the artistic culture of the Baltic people. These are only a few of the acknowledgements bestowed upon Tuulse. Without exaggeration, one can say that Tuulse represented the intellectuals and humanists of the $20^{\text {th }}$ century, who were fascinated by the story of the birth and development of the material world around them. In this way, his creative legacy bears the highest values of art history. And, despite all the serious work he undertook, he never lost the lightness and simplicity of being human, i.e. the ability to find joy in everyday and simple things. That's what's reflected in his letters, which were sent to those closest to him during very difficult times - immediately after leaving his homeland and the time spent in a refugee camp in Sweden.

\section{ARMIN TUULSE'S CORRESPONDENCE}

When mapping the content of Armin Tuulse's correspondence, at first glance, it could be categorised as follows: 1) family letters (overview of living conditions, everyday life and work); 2) personal letters to cultural figures (discussions about art, current events); 3) issues related to the organisation of Estonian art and cultural events, and the preparation and publication of articles and books; 4) the reports and documents of the Estonian organisations operating in Sweden; 5) work-related German- and Swedish-language correspondence and 6) cards, congratulatory messages, invitations, etc. This article includes examples from the first three groups of letters.

The writer Arvo Mägi has recalled how there was a discussion in one of the refugee camps about how long Estonians will survive as an ethnic group in Sweden, before being assimilated by the Swedes: "The predictions ranged from three to five years. And a man that hoped for ten years was derided as a naive optimist."18 It is clear, that the first years after leaving the refugee camps were decisive for the Estonians' culture. During those years, strong mutual ties developed including

17 Ervin Pütsep, “Armin Tuulse”, ETSR Annales VIII, 1977-1979 (Stockholm, 1980), 172.

18 Arvo Mägi, "Enne kukke ja koitu. Pagulaskirjanduse algaastate kultuuripilt", Kultuurileht, 03.10.1996, 5 . 


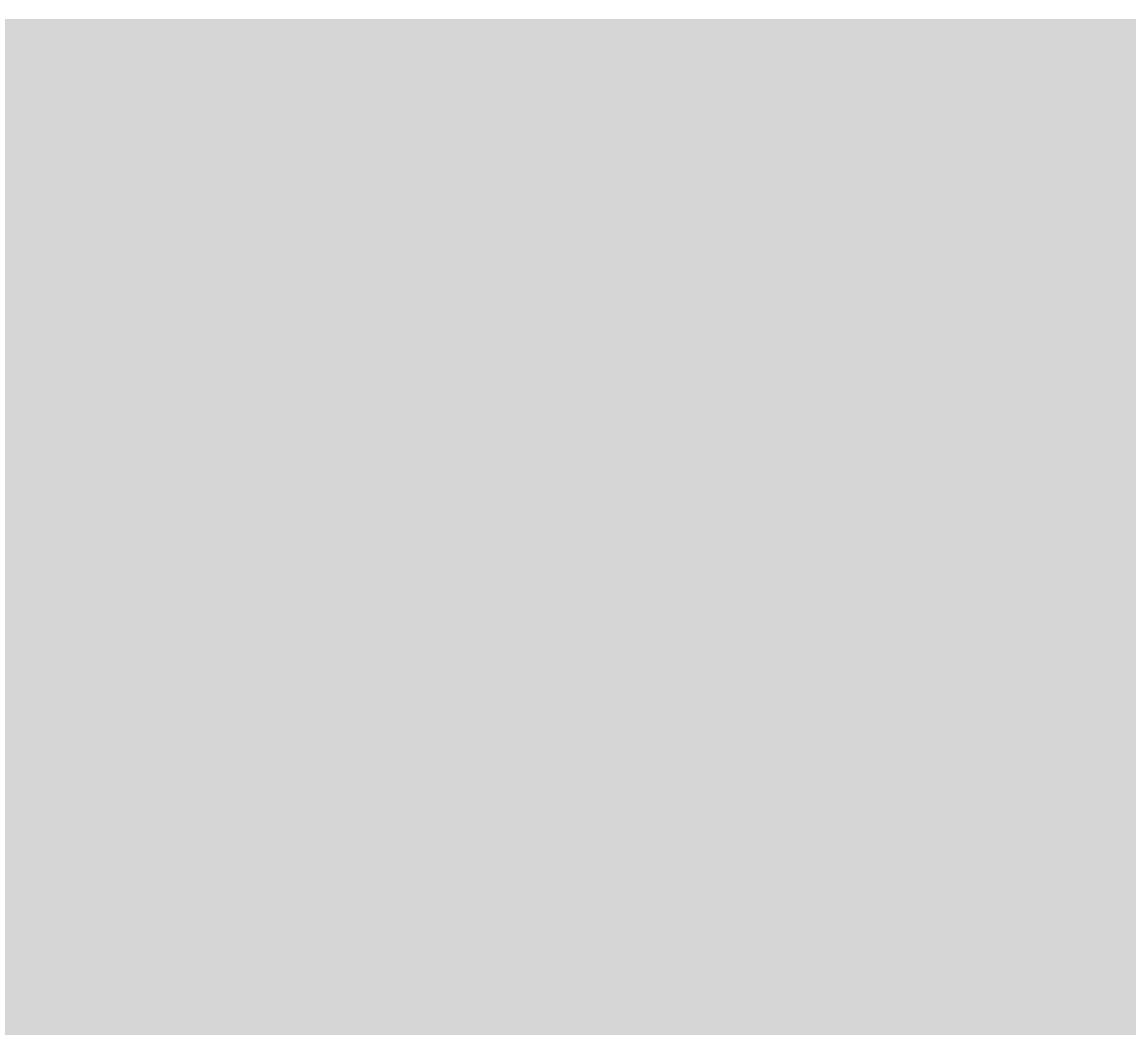

Fig. 3. Armin Tuulse and Liidia Tuulse in Stockholm on 1961. Estonian Cultural History Archives of the Estonian Literary Museum, Tartu.

frequent correspondence and exchanges of ideas, the establishment of Estonian cultural and scientific organisations, etc. The correspondence between Armin and Liidia from 1944 and 1945 provide first-hand glimpses of their living conditions and the difficulties the refugees faced. At that time Liidia, due to circumstances beyond her control, had to stay behind with their son Tanel in the Medevi Brunn camp for Baltic refugees, while Armin was taking the steps to obtain a job and find a place to live in Sweden. The Tuulses arrived in Sweden in August of 1944 and on 12 September, Armin Tuulse writes the following from Stockholm:

Meanwhile, quite a few things have become clear. Firstly, of course, the fact that initially it is impossible to get an apartment in Stockholm, because they no longer want to rent rooms in new houses to foreigners. /---/ With the help of some friends, I was able to rent a small room in Stocksund, a suburb of Stockholm, which costs $80 \mathrm{kr}$. per month. /---/ I will probably get my living permit this weekend, and then I can start work at the Academy ${ }^{19}$. My work there will be associated with my research; I will be given the assignment of researching medieval Estonian churches. /---/ The 'Juhan' arrived yesterday, and people are saying that most of the passengers were Estonians. Who they are is not known. They think two more shiploads can be brought over - so let's hope that many our friends and acquaintances will be here soon.

I've also heard from others that the living conditions in Medevi are not the best. /---/ Last time I promised to send you money, but unfortunately, this isn't possible now, since I had to make a deposit on the apartment. I've also had some expenses in connection with my trips to Stockholm. But as soon as I get my first salary, or an advance, I will come to see you. I'll bring money, chocolate and all kinds of good things. Until then, be well, considering the situation, and please don't be very sad. The situation could have been much worse.

The next month, on 24 October 1944, Tuulse shares information about compatriots and colleagues from the University of Tartu:

Just now a fellow camp resident called me from Laretei' $\mathrm{s}^{20}$ house, and they knew that the Västerås camp is supposed be really bad, only barracks but, in the near future, they are hoping for new camps for the intellectuals near Stockholm. /---/ Laretei told me that Rector Kant ${ }^{21}$ and his family, Uluots ${ }^{22}$, Vendt ${ }^{23}$ and Rebane ${ }^{24}$ have arrived in Sweden. There's no news about any of the other university faculty members arriving, but no one really knows because more and more refugees are flowing in. According to the papers, during the last 24 hours, 400 Estonians have arrived. Laretei had also heard that 3,000 Estonians, including a large number of university

19 Apparently what is meant here is the Kungliga Vitterhets Historie och Antikvitets Akademie

20 Diplomat, politician and military man Heinrich Laretei

21 Geographer and economist Edgar Kant. From 1941 to 1944 was the Rector of the University of Tartu (provisional).

22 Lawyer and politician Jüri Uluots. From 1939 to 1940 was the Prime Minister of Estonia

23 The undersigned is not sure who this person is, but it may be Alfred Vendt, the Economic and Financial Director of the Estonian Self-Administration.

24 Journalist, publisher and political figure Imant Rebane. Founded the Vaba Eesti publishing house in 1954. 
faculty members, had been taken to Finland. Steps have been taken to bring them over. You're probably aware that Pärnu has fallen, so it's only a matter of days until Estonia is totally conquered. /---/ I thank you again for those lovely days, which are really incomparable. My "bronchitis" has disappeared, and I've also found peace and contentment when it comes to other matters, including my mental state.

Armin Tuulse developed close contacts with his colleagues in Stockholm when he was still in Tartu, through his academic research work as well as by working with Swedes on several fieldwork sites. For example, the research and conservation work at the Convent of St Bridget in 1934 and 1935, which was headed up by Sigurd Curman, the Swedish state archivist, and directly managed by Bertil Berthelson, Erik Lundberg and Sten Karling. The acquaintances formed at that time definitely helped him start a new life in a foreign country. ${ }^{25}$ And yet, too much importance should not be placed on the role of acquaintances, because it was Tuulse's own knowledge, excellent reputation as an art historian, language proficiency and indefatigable diligence that became the determining factor.

From subsequent letters, it turns out that Tuulse did not regard the benefits he received for granted and did everything in his power to help other refugees. He also felt a certain sense of humility before those intellectuals who arrived with practically nothing.

On 2 November 1944, Armin Tuulse sends an apologetic note to his wife:

Many thanks for the letter, actually letters, because two of them have arrived in the meanwhile. I'm a somewhat lazy responder, but there are several reasons for this. One is that my correspondence has become very large - I get letters from acquaintances and non-acquaintances asking for advice. I do what I can, and there have been some successes. The latest letters came from Hanno Kompus ${ }^{26}$, then Jakob Koit (head of the History Museum), then S. Veidenbaum ${ }^{27}$ and many people you don't know. They all write about their trips, so in time, an interesting collection of historical letters will develop.

25 Armin Tuulse's family was received in Sweden by architect Erik Lundberg and Bertil Berthelson, a dealer in antiques. See: Kersti Markus, "Armin Tuulse ja kirikute uurimine", Kunstiteaduslikke Uurimusi, 3 (17) (2008), 28.

26 Figure in Estonian theatre and art critic.

27 Journalist and public figure Siegfrid Leonhard Veidenbaum.
On 25 November 1944, he writes from Stocksund to Liidia at the refugee camp:

Many thanks for the letter that arrived on Sunday morning. /---/

What was especially gratifying is that the little boy is better. It's unfortunate that you still haven't got a room, because the weather may turn cold suddenly: every morning I look at the thermometer in fear - but so far, luckily the temperature's been close to zero. So, constantly keep up your guard, and if necessary, be resolute, and even pushy. But in any case, don't let them cajole you into going to another camp, because it will surely be worse than Medevi. I've heard about lots of such sad situations. Recently, Nõmmik ${ }^{28}$ along with his family ended up in one such camp, which was supposed to be one of the best in Sweden. But Nõmmik writes the following in passing: "We're in a so-called permanent camp. However, the only thing that's permanent is the cold. There are only stoves and fireplaces in the small summer houses. We sit in our overcoats and worry about our health... We have to go to the farmhouse 300-400 m away to eat." Compared to that Medevi is a real paradise!

Today, we celebrated Sunday properly. In the morning we read. Then we took a walk around Stocksund and stopped by a nearby medieval church, where a service was in progress. In the afternoon, we went to St Jacob's Church, where the sermon was given by Bishop Kõpp ${ }^{29}$ on the occasion of Estonians Abroad Day ${ }^{30}$ and the day to honour the dead. The church was filled with Estonians, and the national anthem was sung at the end of the service. I saw many tears and sadness, and thought of all who had been left behind. /---/ Tallinn Radio has reported that the university is operating again, but there's a great shortage of faculty members. Koort ${ }^{31}$ is Rector and Tuglas ${ }^{32}$ is Professor of Literature. The Tähtvere neighbourhood is supposedly still the place where the faculty members live - so that it's possible that our apartment is now occupied by a fresh comrade-professor!

Hanno Kompus visited me recently. He came with the last ship, and was forced to leave his only two suitcases on the dock-so he arrived with empty

28 Artist Juhan Nõmmik

29 Johan Kõpp was the bishop and archbishop of the Estonian Evangelical Lutheran Church from 1939 to 1964 and the rector of the University of Tartu from 1928 to 1937.

30 The Estonians Abroad Day organised by the Association of Estonians Abroad took place every year on the last weekend of November.

31 Estonian philosopher Alfred Koort was the rector of the University of Tartu from 1944 to 1951 .

32 Estonian author Friedebert Tuglas. 
hands! Compared to them, we're quite wealthy, and I would have definitely felt guilty before Estonia's leading intellectuals who are our acquaintances if we had come with a "full load" of baggage. So, at least I'm partially on the same footing as they, and can, with understandable wonder, observe their irreverence toward all earthly "trash and debris"- be it silk blankets or necessary clothing.

The role Armin Tuulse played in helping the newcomers is also manifested in a message sent from artist Jaan Grünberg on 8 January 1945, which was mailed from a town called Mölle:

I received a letter from $\mathrm{Mr}$ Uustalu ${ }^{33}$ a few days ago, in which he says that you may be able to help Estonian artists get some paints, and he suggested that I approach you in regard. Since I have no paints now, I would be very happy if I could get them. Unfortunately, I would not be able to pay for them right away. I have a couple of small paintings, which I haven't even tried to sell here in Mölle; but if the opportunity to sell them should arise, I could cover the debt for the paints.

On 26 January 1945, a joyful message arrives from Stocksund to Liidia Tuulse - it was time to start making preparations for leaving the camp and moving to Enskede ${ }^{34}$. It's clear from the letter that, with the help of some friends, Armin has been able to get some old furniture from the Royal Coin Cabinet, including "carved 'conference chairs' with high backs for our 'dining room', and a table that can be used for dining, as well as bookcases, which it will take me some time to fill up". He also warns his wife that those coming from a camp will have to undergo a 'bedbug control' upon arrival in Enskede, and "if they find something suspicious, there's the threat of sulphur smoke, or something even worse!"

Armin Tuulse and Liidia Tuulse continued a lively correspondence for years. The main reason was Armin's frequent trips to participate in excavations and research projects. At the same time, the letters sent from the fieldwork sites provide today's researchers with interesting information about the excavations in Sweden during the 1940s and 1950s.

33 Historian Evald Uustalu

34 A neighbourhood of Stockholm. The famous Skogskyrkogården (Woodland Cemetery) is located in Enskede, a part of which comprises the so-called Estonian cemetery.
From Armin's letter from Sölvesborg, sent on 28 October 1945, we learn that fieldwork could last for weeks, and in this case, for a month:

The restaurant [Slottrestaurant] is located on the edge of town - about a ten minute walk from my workplace. A wonderful white building under ancient chestnut trees, with the ruins of the Sölvesborg Castle tower visible from the window. And therefore the name.

The town itself is about the size of Valga, but its architectural style is somewhat reminiscent of Tartu. The grandeur and noise of Stockholm is lacking here, and in the evenings, when I walk from the eatery to my apartment (which is located diagonally across town), I sometimes get the illusion that I am walking in Valga, Tartu or Rakvere. /---/ With its provincially poor street lighting, it is here that one can get an illusion of being back home, although that the trees and bushes in the gardens are slightly larger, and the street paving is slightly better. But only sometimes. /---/

And finally, the most important matter: the excavations. Despite the bad weather, they have progressed quite well, because the three workers are fervently interested in the project and do excellent work. Since to date only a minor part of the wall has been exposed, no actually measuring has been done. And when it will be, it will not be very strenuous - especially after the dress rehearsal at the Mörby ruins. I've also partially plotted the previously excavated area, although I was told that it had already been plotted. However, after several requests, I have yet to see these plans, and thus, I thought that before securing the old walls (with the excavation soil from the new part), I should record all the walls on paper, just to be sure. /---/

So, thank heavens, I'm satisfied with the living and working conditions here. /---/ My only worry is you little rascals, but soon a week will have passed, and probably the remaining three weeks will pass by quickly as well./---/

Armin and Liidia Tuulse's correspondence reveals the mutual support provided by the spouses to each other, as well as their everyday and work-related issues. Assessing the letters sent to Tuulse by the exile Estonian cultural figures in Sweden, his central role in the local Estonian community becomes ever more apparent. People wrote to him with official and private questions, and he served as a natural advisor to artists and scientists, and an authoritative person in the solution of several problems.

The diversity of his literary work becomes apparent from Armin Tuulse's bibliography. Besides architecture, he also displayed an 
ongoing interest in the fine arts, and art philosophy more generally. For example, he was the initiator and author of the text for a book published by the Estonian Fine Artists Centre called Eesti kunst paguluses (Estonian Art in Exile) ${ }^{35}$, which was the first attempt to provide a survey of the artistic creation of Estonians in exile. $\mathrm{He}$ also continually published exhibition reviews in Sweden. Tuulse's correspondence shows that he did not limit himself only to official art criticism and writing, but was also involved at personal level by giving advice and discussing philosophical questions related to art

On 20 November 1945, artist Eerik Haamer writes from Gothenburg:

You advised me to paint larger paintings. I tried one. For the first time in my life, I dealt with an old story. It was one about an unmarried girl with a child who was exiled from an island. She was put into a boat without oars that was supposed to be carried off by the wind. ${ }^{36}$ The painting is $130 \times 190 \mathrm{~cm}$. So, it's quite big. I spent more than a month painting it. I asked /---/ for permission to paint it in one of the museum's storerooms, which has ceiling lighting. /---/ I worked on it in the morning (then it was still light) before going to work, during my lunch breaks and in the evenings after work, as well as all day Sunday. /---/ I was often tired when I went into the room, and I was hungry after the long workday, but everything was forgotten when I was there. It was already quite dark when I left, and I said to the girl in the picture, they won't send you away after all, they'll reconsider. When everyone has gone home, the collections are as silent as the grave, and it was good to be there with my friends, the paints, they are like living beings if you know how to love them.

35 Eesti kunst paguluses, text by Armin Tuulse (Örebro: Eesti Kujutavkunstnike Keskus, 1954), 36 The artist has been inspired by the tradition of the coastal people of Ruhnu to drive unmarried mothers out of society in this manner, which is known to have still been practiced in the $20^{\text {th }}$ century. Based on the description, the painting may be Väljatốagatu (oil, masonite, 1945), which is now in the Viinistu Art Museum. The painting has been described by Lilli Kaelas, who which is now in the Viinistu Art Museum. The painting has been described by Lilli Kaelas, who
studied art history with Sten Karling: "---/ in the most monumental painting Väljatôugatu, he describes convincingly, with a sincere feeling of reality, a dramatic scene from the life of the Ruhnu islanders, in which an unmarried mother with child is pushed out of the island's morally strict society and sent in an open boat without oars to be destroyed by the windy open seas. In his work, the artist depicts the moment when the young mother with child arrives on the beach having been sent their by the villagers. With astonishing psychological authenticity, Haamer ha depicted the strange apathy of the main character, her expression that of person who has already surrendered to her fate and accepted her death," See: Lilli Kaelas, "Eesti kunst Rootsis. Eesti Ja läti kunstinäitus Stockholmis", Kodukolle, 2 (February) (1946)
On 2 February 1954, artist Arno Vihalemm writes from Ystad:

What can I tell you about my life? I'm still vegetating here, and wheezing and grumbling. And I can't even look forward to the ice melting - after all, the sea doesn't freeze here. /---/ I've started working in oils again. I stop totally for a couple of years. As you know, I've gotten stuck somewhere with my realism-naturalism, run aground, beached. I can't move forward, or actually, this style no longer satisfies me, because what I felt, what I "wanted to say" no longer fit into that framework. It was always more of seeking a compromise. And it was terribly hard to "find a motif", as you may remember. Barren land and a beach with its black boats also started - like fatal fixations - to annoy me. /---/ After all, couldn't I paint some other way, so there would also be fish in the sea? Without even having to paint the sea! To paint about one's own impotence, people's impotence - when finally, there's no other alternative!

The dominant themes that arise from the correspondence are related to art and cultural events, economic conditions (where and how to sell my works, etc.); now and then more difficult issues arises the political situation in the homeland. On 28 March 1946, Eerik Haamer writes:

It's been oddly quiet in the Stockholm area, no letters or anything arriving. /---/ What do they thinking about world affairs over there? This morning it was quite good to hear that the Russians are starting to take some heat. I hope it doesn't just die down again. I don't go out much, but at work one day the men are cheerful and happy, saying everything will be all alright. Soon we can pack our bags and go home. But the next day, there's no hope, the situation is sad and unclear. People are in a bad mood. Everything is going wrong. That's how it is, one day one mood, another day another. /---/ I have the feeling that people's patience is coming to an end. This is a bad thing. This is difficult if you pay attention to other people. I'm especially sorry for the older people. Home sickness is hard to bear in the springtime /---/. Sometimes, I stay up later at night and look at how the room is filled with things, how the children are sleeping. The boy's cheeks are red and luckily, the girls have also been well. It is so calming to observe all this. I think, at least I have something to worry about and work for. This is a comfort during this dark time. You don't need anything when you are surrounded by children, life goes on /---/. 


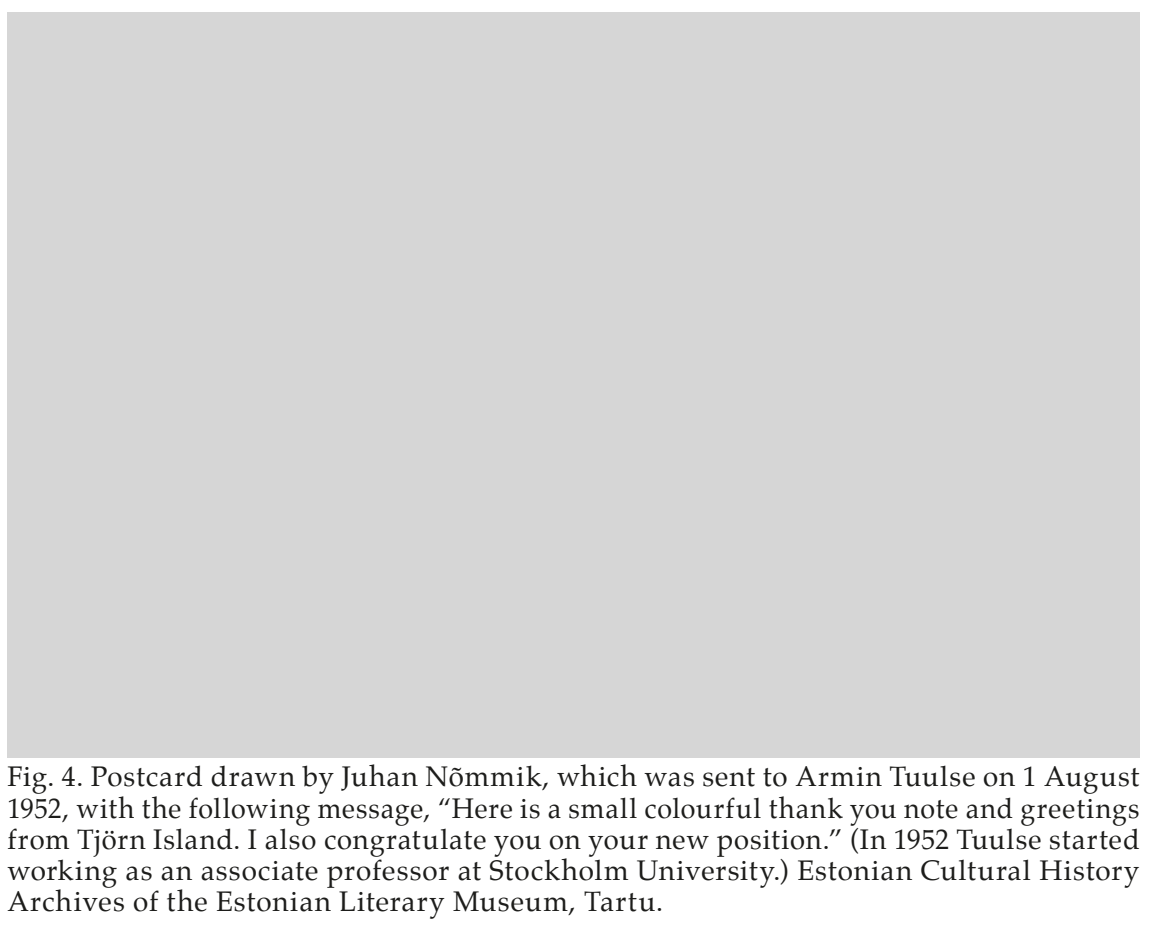

The next month, on 20 April 1946, Haamer congratulates Tuulse on the birth of his second son, Toomas, and says, "I believe that during such difficult times, it is one's family that keeps a person fresh."

In the spring of 1945, the first Estonian exhibition in exile took place at the Värmland Museum (in Karlstad). ${ }^{37}$ Tor Helge Kjellin was the initiator of the exhibition, which included 146 works of art by 26 artists. ${ }^{38}$ The exhibition later travelled to other large cities in Sweden (Liljevalch, Lund, Göteborg, etc.).

37 An article appeared: Nth J. [Nathan Jonson], "Estnisk konst på Värmlands museum”, Nyd Wermlands-Tidningen, 19.04.1945. This article focuses on the work of the following artists Osvald Eslon, Eerik Haamer, Konrad Magi, Raoul Lind, Harri Laks, Karin Luts, Ants Murakin, Talvik. In addition to artists named in the review, the exhibition also included works by Salme Schönberg-Riig, Olev Mikiver, Arno Vihalemm, Otto Paju, Juhan Nõmmik, and others.

In his letter to Armin Tuulse (24.04.1945), Bernard Kangro notes, "The writer of this article is Nathan Jonson (I think that's the name), a local art critic, and school teacher. In addition, general article appeared in the Karlstads Tidningen, which I will also send you. Of course, it is embarrassing that Nômmik is not mentioned, but what can we do, that's their affair."

38 Anne Valmas, "Kultuurielu algus Rootsi paguluses", Kultuurileht, 30.09.1994, 10.
In addition to Kjellin, another organiser of the exhibition was Bernard Kangro, who on 16 March 1945, wrote to Tuulse from Karlstad, to provide him with an overview of the organisational issues related to the exhibition:

Unfortunately, Professor Kjellin is not here now and this makes it impossible to take some steps for which we have no authorisation. This includes the application to Consul Nerman, and the issues related reimbursing the costs for packing of the works coming from private collections. However, the artists will have to pay for packing their own works. There are also some difficulties with the issue of liability related to the owners of the private collections. Actually, I don't think we have to fear that anything will get lost and it should be possible to prevent any damage with sensible packing. The works will be shipped by rail as "fraktgods" ["cargo"], and the shipping costs will be paid by the Museum, and well as the costs for the return shipping.

Currently we have affirmative answers from Eslon, Haamer, Ole, Luts, Schönberg-Riig, and Talvik. For a total of about 40 works. Although, we're still waiting for replies /---/, there are still too few. /---/ But, we will definitely need some works from private collections. And then our main hope is Stockholm. Without names like Raud, Triik, Laikmaa, Mägi, Viiralt, etc. etc. our exhibition will not be sufficiently imposing... /---/ But, where and from whom can we get them? Do you personally have anything with you? And could you send them? /---/ I wrote to Prof. Karling a few days ago and am awaiting an answer. Here in this city, the Estonians have a few things, and of course, we can get those. We have: Viiralt's 'Berber Girl with a Camel', 'Semi-Nude', 'Virve', 'Viljandi Landscape', 'Arkeia' (I don't know the exact title, unfortunately), 'Birth of a Woodcut'; Jansen's ${ }^{39}$ 'Estonian Landscape'; Aren's ${ }^{40}$ 'Two Girls'. What we can get from Gothenburg, we don't know yet. /---/

However, who could help us with the organising in Stockholm, perhaps Mrs Luts? Of course, I will also write to her, but try to keep our matters close to your heart, as you have done to date.

The next month, on 10 April 1945, a letter from Kangro, who was feeling dispirited arrived, which reflected the stress and amount of work involved in organising the exhibition. And it expressed the difficulties faced by an Estonian organising an exhibition and catalogue in a foreign country:

39 Estonian artist August Jansen

40 Estonian artist Peet Aren. 
I am sending you the Karlstad art exhibition catalogue with quite a heavy heart. Actually, I would prefer not to do so at all, because there are many things that don't satisfy me, and not to mention a more demanding and competent person. Now that all the difficult work and worry is behind us, I am overwhelmed by such a feeling of disappointment and emptiness that I am barely able to compose myself enough to write you a few lines. But I feel that I should do so for some reason. The experience of making the frames together and painting them from 8 in the morning until 10 at night, of all of us sticking together and wanting to do everything as best we could was very beautiful. Now that the exhibition is up and has been well received, and can considered to be more or less successful, I am still bothered by some small details, so that all the joy had gone out of this work and will probably never return in the same way. We are caught between fronts here. On the one side, there are the opinions and understandings of the Estonians about the whole thing, and on the other, those of the Swedes. And two don't exactly coincide. We did everything possible to defend our positions, but since we didn't receive any art-related help from Stockholm we had to make some concessions. Thus we could not adhere to their position that totally unknown artists should not be included. They came themselves, and the professor had also recruited some at his own initiative. Namely, he is an idealistic friend of youth and won't budge from that position. This might be right, but, when looking at the catalogue, the proportions related to the introduction of Estonia get a bit confused. But, ultimately, these are the provinces, and the expectations are not as high as in they are sometimes in that far-off and beautiful capital. /---/

And also, there are mistakes in the catalogue. This is the fault of the Swedes who simply didn't send me the text for proofreading as they had promised, but just had it printed. Actually, we're lucky it turned out as well as it did. Considering the tempo and mode of operation, it could have turned out even worse. So don't be too angry and take into consideration the fact that organising things in a foreign country is not as easy as in our dear old homeland. /---/

Thanks to Professor Kjellin's friendly attitude and bold opening speech the opening day of the exhibition was unexpectedly successful. We sold more than ten works of art on the first day, and considering the local conditions, this was said to be not bad at all. In any case, the professor did every he could and will do so henceforth. The local newspapers are very positive and the exhibition seems to be attracting visitors.

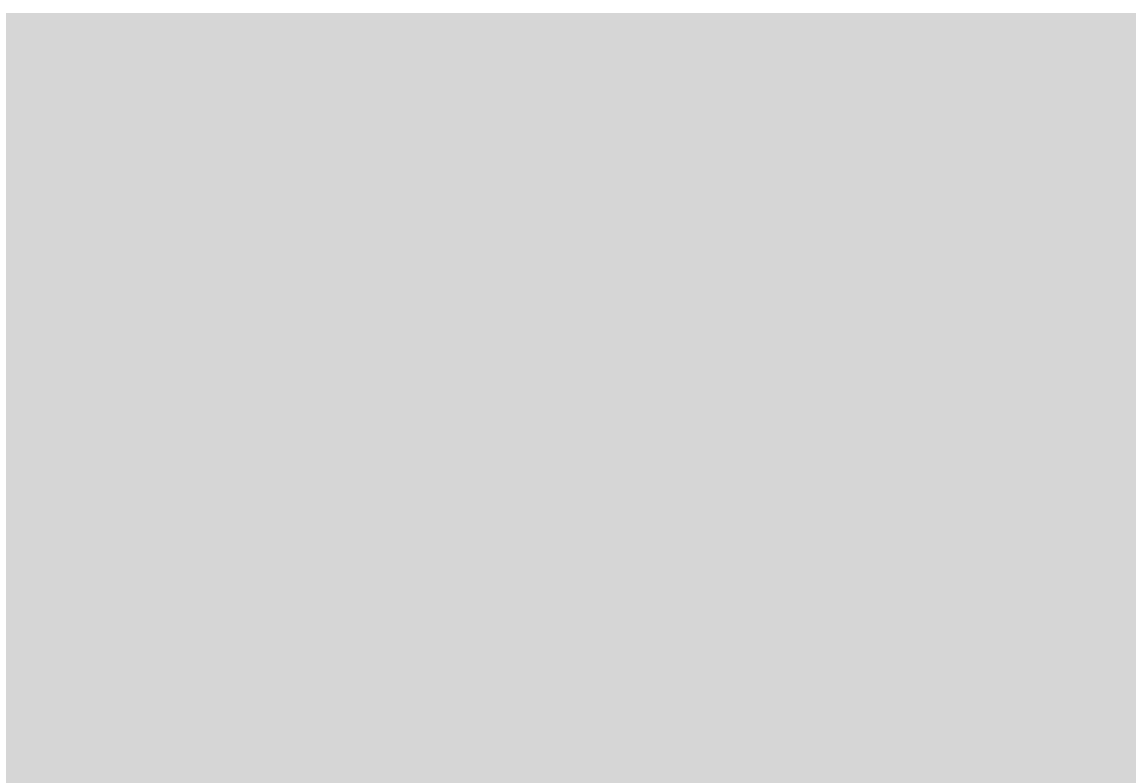

Fig. 5. Eduard Wiiralt in Sweden on 1946. Art Museum of Estonia, Tallinn.

In 1954, one of the most contentious issues among the exile Estonians in Sweden became Wiiralt's legacy, and making the decision about its fate also fell to Armin Tuulse. On 7 January 1954, Tuulse received a letter from the Estonian Fine Artists Centre, which says:

As has become generally known, graphic artist Eduard Wiiralt has fallen very seriously ill and underwent a serious operation before Christmas. Although this was successful and E. Wiiralt's life was saved, the artist will need to be in a rest home for longer period in order to recover his health and creative ability. The Estonian Fine Artists Centre considers it selfevident that we have a responsibility to our greatest contemporary artist, whose name and work have brought only recognition and honour to the Estonian people, to help him sustain his creative ability and life for many years. To achieve this, the centre will immediately organise a rapid sale of his works /---/. ${ }^{41}$

Eduard Wiiralt died a day later on 8 January 1954 in Paris. On 26 January 1954, art historian Rain Rebas writes Tuulse a long letter

41 The letter includes a list of "Works to be sold", which has a selection of Wiiralt's works with prices. 
about Wiiralt's legacy, commemorative exhibition and monograph, in which, among others, he names Tuulse as an important specialist regarding this question:

I read the article you wrote on the occasion of Eduard Wiiralt's death in the Teataja [newspaper], in which, at the end, you also touch on the questions that are of extreme importance in the present situation. I have definitely arrived at the conclusion that the only possible solution is for the Estonian Fine Artists Centre to form a committee that will be totally responsible for, dealing with the Wiiralt question and have the competency to do so. In addition to the organisation of exhibitions (and making sure they occur in the right way!), public commemorations, and a monograph, many other urgent problems may develop, for example, preventing the future use of Wiiralt's printing plates, organising the materials he left behind, and generally the issue of people with various qualifications, who will probably try to take advantage of the situation and profit from it in any way possible.

I have received several letters. One was from artist Nommik in Paris, which was sent via Haamer. It seems that, according to Nõmmik, the situation is good and things are more or less in order. This has probably been helped by the fact that Nõmmik himself is in Paris. It was definitely necessary to send a person qualified in art matters from Sweden to Paris. When Nõmmik returns perhaps something can be done to provide a secure and dignified foundation for dealing with this situation. I myself have suggested (I have also written to Haamer and Nõmmik about this) that such a committee should be comprised of Prof. A. Tuulse, artists J. Nõmmik and E. Haamer. I believe this would be the best arrangement in the interests of protecting Wiiralt's legacy. Whereas, all the questions that may arise that require competent expertise (which currently does not exist!) would be decided by this committee. I even dare to think that most probably no obstacles to organising such a committee exist. /---/

On 5 February 1954, Tuulse receives a concerned letter from Rebas: I have now received information about the Wiiralt issue from several sources. And, at the worst moment, the events, as if impacted by some sad forces beyond our control, have started to develop as I was afraid they would - Rannit-Dolgošev's ${ }^{42}$ immense activism, the plan to take Wiiralt's legacy to the U.S., Minister K. R. Pusta's ${ }^{43}$ positive attitude toward this, etc. - so I would be very thankful if you would express your opinion in a few words regarding this very complicated issue. And what reasonable assistance could be organised to decisively resolve this issue in the right way, and how could it be mobilised?

Because, a situation has now developed whereby the future Estonian art research related to Wiiralt is at a crossroads, and much depends on the resolve with which those people, who should be the ones that we look to with confidence, are able to act in this situation.

The issue of Wiiralt's legacy was not resolved for a long time, and on 29 June 1954, a serious letter arrives from Endel Kõks, who is writing on behalf of the Estonian Fine Artists Centre:

I got a letter from the U.S. saying that, at a meeting of the local Eduard Wiiralt Association in New York, it was decided that the dead artist's legacy - plates, correspondence, etc. - should be sent to the U.S. The meeting was attended by the board of the association as well as $\mathrm{Mr} \mathrm{Kaiv}{ }^{44}$ and Mr Pusta. According to the information that was received, one of the motives for this transfer is a plan to use the surviving plates to make prints and sell them.

At this point, I would like to remind you that on February $15^{\text {th }}$ of this year, we notified both Minister Pusta in Paris and the board of the Eduard Wiiralt Association in New York, of our position, in which we stated that the place for the deceased artist's legacy is Europe; and suggested that, if necessary for security reasons, it could be transferred to England, since a legal representation of the Republic of Estonia is located there. And this is also a place that is equally accessible to interested parties from America and Europe. /---/ I would like stress herewith that the Estonian Fine Artists Centre does not plan to start vying for the artist's earthly legacy, but it is our wish not to create a situation in which only one person, or very few people, can dispose of his legacy. I would be thankful if you formulated your position is such a way that we could use it take joint steps, and to synchronise our positions before making them public.

On 17 August 1954, Rain Rebas writes from Paris:

I left Gothenburg on Sunday morning and arrived in Paris at midday yesterday. This morning I went to the Père-Lachaise cemetery. Wiiralt's grave is easy to find and in good order. /---/ 
I wrote to Pusta on 01.08.54.: "In order to resolve all the competencerelated and special issues (which deal with individuals, the artistic side of the legacy and its organisation, as well as the significant changes related to the status of the legacy), in the current situation it is undoubtedly necessary, since Eduard Wiiralt is an Estonian fine artist, to listen to the opinions of professors Sten Karling and Armin Tuulse, as well as the Estonian Scientific Society and the Estonian Fine Artists Centre. /---/

In the meanwhile, the Estonian Writers Cooperative, at the initiative of Bernard Kangro, was able to publish a commemorative book called Eduard Wiiralt. 1898-1954..$^{45}$ On 2 January 1955, Tuulse writes to Bernard Kangro and thanks him for the commemorative book - "its impeccable appearance was a great joy and surprise. There are few such books in Estonian art literature, if any." Tuulse's article titled "Noor Wiiralt Pariisis" ("Young Wiiralt in Paris") appeared in the book, the last sentence of which says: "He became a Parisian, although a Parisian who has been called an unsociable autodidactic and the physiognomy of his work clearly defines his origins. He preserved 'his Nordic integrity ... which he brought with him to the south from the edge of the Baltic Sea' (Basil Burdett). Now when the artist has passed into eternity, it should be our relentless aspiration and obligation to preserve his legacy for Estonian culture." ${ }^{\prime 46}$

Among Tuulse's letters is the draft of the deposit document dated August 1957, which was drawn up by Tuulse as the chairman of the Estonian Committee, which says: "The Estonian Committee in Sweden, as the manager of the deceased artist Eduard Wiiralt's property (negotiorum gestor), deposits Ed. Wiiralt's property in the Royal Swedish Academy of Fine Arts, with the gracious consent of the latter, based on a list that will later be added to this document."

The artist's few personal possessions and engraving, drawings, sketches and designs, as well as graphic art plates, remained behind at his last residence. Along with the artist's diaries, correspondence, photos, documents, books and exhibition catalogues. The fate of the legacy was decided at the initiative of Kaarel Robert Pusta. Hoping for the restoration of Estonian independence in the future, it was decided that it should be preserved in Stockholm and managed

45 Eduard Wiiralt. 1898-1954 (Lund: Eesti Kirjanike Kooperatiiv AB, 1955).

46 Ibidem, 52 by the Estonian Committee. With the help of Sten Karling, former Professor of Art History at the University of Tartu, Wiiralt's legacy was transported to Stockholm, where it was initially stored in rooms belonging to the Academy of Fine Arts in Fredsgatan. In 1987, it was transferred to the Swedish National Archives in Mariaberget. In April of 2005, the Estonian Committee in Stockholm transferred the most significant part of Eduard Wiiralt's legacy to the Art Museum of Estonia - 323 engravings, 919 drawings, sketches and designs, as well as 84 printing plates. ${ }^{47}$

\section{IN CONCLUSION}

Narrative sources, such correspondence or personal memoirs, are not a priority in historical science. The main reason is their subjectivity and the conscious or unconscious choice of the authors regarding what to record and how to record it. Correspondence is always impacted by the personal attitudes of the writer and the recipient, and their mutual relationship, as well as the ideological background and cultural context. An yet, private correspondence has always fascinated historians and cultural scholars, by provided a new point of departure for the interpretation of the past, and providing information that is not always available from so-called official or public documents. Since the correspondence between exile Estonians occurred in a free atmosphere and without censorship, it differed significantly from the communication process in Soviet Estonia. Literary scholar Eve Annuk has written that, when researching the Soviet era, it is important to distinguish between the public and private spheres, but even private correspondence could be monitored by the authorities. This mean that, as a material fact, a letter could function as so-called evidence that could be used against the writer, and therefore, self-censorship also played a role in private correspondence. ${ }^{48}$

When dealing with correspondence, one must be aware of its subjectivity and maintain a degree of scepticism regarding the sources of the material. However, the proper interpretation of letters may yield valuable and first-hand knowledge about the concerned parties,

47 Mai Levin, "Eduard Wiiralti pärand - Eesti Komitee kingitus": http://kumu.ekm.ee/eduardwiiralti-parand-eesti-komitee-kingitus/ [viewed 15.07.2017].

48 Eve Annuk, "Totalitarismi ja / või kolonialismi pained: miks ja kuidas uurida nõukogude aega?", Võim \& Kultuur (Tartu: Eesti Kirjandusmuuseum, 2003), 22-23. 
in this case about the lives and work of the exile Estonians. Cultural historian Aili Aarelaid has used the term "the art of survival" to describe Estonia in the 1940s. ${ }^{49}$ Although, Aarelaid had the local post-war cultural situation in mind, the term applies just as well to the refugees that left Estonia. In addition to personal survival, the preservation of the Estonians' identity and culture was also at stake. In regard to the latter, the contacts and active communication between the exile Estonians, which was based mostly on writing, became a determining factor. Therefore, the role of correspondence in the promotion of Estonian culture outside of Estonia should not be underrated.

The functional mechanism of the exile community was hidden in its joint activities - establishing central Estonian cultural and scientific organisations, organising art exhibitions, writing and publishing books. Since Armin Tuulse had already established good contacts with his colleagues in Sweden and elsewhere in Europe before his departure from Estonia, he became an important person in the coordination of Estonian cultural life in Sweden. Armin Tuulse's correspondence provides a clear and systematic survey of the living conditions and ancillary activities of the Estonians who escaped to Sweden. His correspondence provides a lucid overview of how the first exile Estonian exhibitions were organised and the problems encountered in the publication of written materials. And what continuing his research work as an exile in a foreign country meant to a University of Tartu faculty member. In connection with the latter, this correspondence also provides additional information about the development of Estonian art history - this means the continuation of the research work started at the University of Tartu in the Nordic region.

The nature of Tuulse's correspondence, which is mostly workrelated and explicit, allows the material found therein to be treated as a trustworthy source. In exile it was important to continue the work that had been left unfinished in Estonia. And yet, one cannot ignore the human dimension of the correspondence, which undoubtedly adds subjective emotionalism to the letters, as well as hidden psychological aspects. The complicated political situation in homeland, the concern about the family and friends left behind, and starting all over in a

49 Aili Aarelaid, Ikka kultuurile mõeldes (Tallinn: Virgela, 1998), 176-177. new country with empty pockets were only some of the difficulties facing the exiles. Obviously, correspondence not only played a role in resolving organisational issues related to cultural life, but was also a way to overcome psychological setbacks. And thus, on 19 October 1957, after ten years of exile in Sweden, artist Eerik Haamer wrote the following: "I often think of old chums. About Nõmmik - about you - yes, what - I even don't know what - but I get a warm feeling, and am glad that you exist."

The passages included in this article are only a small fragments of the voluminous correspondence that provides the reader an opportunity to sympathetically step into the shoes of a refugee in a foreign country. And even more, Tuulse's correspondence, which is now in the Estonian Literary Museum, provides a large amount of source material for the research of the development of art history and exile culture, and of course, the creative legacy of Armin Tuulse and his wife, Liidia Tuulse.

Kadri Asmer: Letters From the Past: Armin Tuulse's Archive IN TARTU

Keywords: Armin Tuulse; Sten Karling; Exile Estonians in SWeden; Exile Estonian CUlture; Correspondence; Eduard Wimalt; Department of Art History, University of Tartu

\section{SUMMARY}

In 2015, the correspondence of Professor of Art History Armin Tuulse (1907-1977) and his wife Liidia Tuulse (1912-2012), which dates back to 1944 when the family escaped to Sweden, arrived at the Estonian Literary Museum. A significant part of the archive is comprised of the correspondence between the spouses, along with frequent contacts with exile Estonian cultural figures and Armin Tuulse's work-related communications with colleagues in Europe, the U.S. and Australia. The main objective of this article is to take a first look at the material and highlight the main points of emphasis in the correspondence of the exile Estonians in the 1940s and 1950s. 
At that time, the main issue (in addition to worries about everyday hardships and living conditions) was related to the continuation of their work and keeping Estonian culture alive in a foreign cultural and linguistic space.

In order to understand Armin Tuulse's position in Sweden, the article also takes a look back onto his activities in the Department of Art History of the University of Tartu in the 1930s and 1940s, when Sten Karling (1906-1987) from Sweden came to teach in Tartu. Under Karling's guidance, Tuulse became a dedicated scholar and later the first Estonian to become a professor of art history.

\section{CV}

Kadri Asmer (b. 1985) is a PhD student in the Department of Art History at the University of Tartu and the editor of the Baltic Journal of Art History. In addition to her academic work, she curates exhibitions and writes art reviews. In 2013, an anthology titled Armin Tuulse. Linnad ja lossid was compiled by Kadri Asmer. 